\title{
Unravelling the bacterial diversity found in the semi-arid Tablas de Daimiel National Park wetland (central Spain)
}

\author{
Giuseppe D'Auria ${ }^{1,2, *}$, Maria Mercedes Barón-Rodríguez ${ }^{1}$, Ana Durbán-Vicente ${ }^{1}$, \\ Andres Moya ${ }^{1,2}$, Carmen Rojo ${ }^{1}$, Amparo Latorre ${ }^{1,2}$, Maria A. Rodrigo ${ }^{1}$
}

\author{
${ }^{1}$ Cavanilles Institute for Biodiversity and Evolutionary Biology, University of Valencia, Polígono de la Coma s/n, \\ PO Box 2085, 46071 Valencia, Spain \\ ${ }^{2}$ CIBER en Epidemiología y Salud Pública (CIBERESP), Barcelona, Spain
}

\begin{abstract}
Our knowledge of microbial diversity in the environment is still limited, and there are many species as yet unidentified in both soil and water. Studies of the microbial diversity of wetland ecosystems have been neglected for years, as is the case of Tablas de Daimiel National Park (TDNP), a Spanish semi-arid wetland system of international importance in terms of waterfowl. We report the bacterial diversity of water column, sediment (upper and lower layers) and biofilm samples from the TDNP system using a 16S rRNA gene library approach. A sequence comparison of the 703 clones obtained revealed a number of bacterial phylogroups unreported to date. Bacterial diversity was high (Shannon values of 3.2 to 4.9), with the highest corresponding to the water sample, followed by the water-sediment interface (upper sediment). The sequences affiliated with the Proteobacteria and Bacteroidetes phyla were the most frequently found. Sequence distribution corresponded closely between the water column and upper sediment layers on the one hand, and the lower sediment and biofilm layers on the other. Gamma- and Deltaproteobacteria were the most dominant groups in the clone libraries from samples of water and upper sediment environments, whereas Alpha- and Betaproteobacteria were dominant in lower sediment and biofilm. In total, 265 new phylogroups were found with less than $97 \%$ similarity to the closest taxonomically defined 16S rRNA gene sequences in public sequence repositories.
\end{abstract}

KEY WORDS: Microbial communities - Bacterioplankton - Sediment - Water-sediment interface · Biofilm $\cdot$ 16S rRNA $\cdot$ Wetlands

\section{INTRODUCTION}

Wetlands play an important role in maintaining biodiversity (Mitsch \& Gosselink 2000). However, studies of the microbial component they harbour (especially bacteria) have been neglected for years. Although molecular markers were first used to determine bacterial diversity some 20 yr ago (Bottger 1989, Weisburg et al. 1991, Baker et al. 2003), most studies of natural wetlands only report data about total bacterial biomass (Ortega-Mayagoitia et al. 2002, Farnell-Jackson \& Ward 2003, Rodrigo et al. 2003). Molecular fingerprint- ing and cloning techniques have been applied to ecological studies in wetlands quite recently. Some authors have described the microbial community structure from meso- or microcosms studied in artificially constructed wetlands (Ahn et al. 2007). However, there are few studies of the diversity of natural microbial communities of water, water-sediment interfaces or biofilms in wetlands (Baik et al. 2008). Moreover, since the extent of microbial diversity in nature is still largely unknown, there might be many more species from soil and water wetland environments yet to be identified (Hahn 2006, Ghosh et al. 2007). 
Tablas de Daimiel National Park (TDNP), located in the centre of the Iberian Peninsula, is among the most important Spanish wetland systems. In 1940, it covered about $150 \mathrm{~km}^{2}$ (Heras et al. 1971), although currently it is greatly diminished (Alvarez-Cobelas et al. 2001). TDNP has been subjected to drainage policies during the last $60 \mathrm{yr}$, mainly to extend agricultural lands (Cobelas et al. 1996). Water pollution, mainly organic matter, nitrogen and phosphorus, coming from point (towns and agro-industry) and non-point (agricultural practices in the watershed) sources, started in the late 1970s and reached a peak by the middle of the following decade, decreasing later as a result of newly implemented water-treatment plants in the catchment area. Water availability became limited between the late 1970s and the 1990s because of irrigation programs, which depleted the groundwater aquifer. Despite this, the land is still valuable in terms of its waterfowl populations (particularly the red-crested pochard Netta rufina Pallas) and plant species (e.g. the macrophyte Cladium mariscus [L.] Pohl). TDNP was designated as a Special Protection Area in 1979 (EU Birds Directive). It has also been a RAMSAR site since 1982 (Convention on Wetlands of International Importance, Iran, 1971; www.ramsar.org). The biodiversity of most biological compartments of this ecosystem is well known (phytoplankton, zooplankton, fish, vegetation; Cirujano et al. 1996, Rojo et al. 2000, Ortega-Mayagoitia et al. 2002). By contrast, the bacterial diversity it shelters is still unknown. This study aims to describe the bacterial diversity inhabiting this environment using the $16 \mathrm{~S}$ rRNA gene as a molecular marker; clone libraries were constructed for 4 kinds of samples from this wetland environment: water, water-sediment interface, sediment and biofilm, taken during the summer season.

\section{MATERIALS AND METHODS}

Sampling site. TDNP is a semi-arid floodplain located in central Spain $\left(39^{\circ} 08^{\prime} \mathrm{N}, 3^{\circ} 43^{\prime} \mathrm{W}\right.$, Fig. 1), which has been subjected to fluctuations in the water table arising from the interaction of surface flooding due to stream- and groundwater discharges and water retention by watermill dams. The highly variable hydrology leads to fluctuating hydrologic connectivity patterns and hydroperiods. Its watershed is about $13000 \mathrm{~km}^{2}$, underlain by Pliocene limestone, marls and calcretes, but its discharge into TDNP is low due to water diversion for heavy agricultural irrigation. Due to these changes in water availability and extensive irrigation of surrounding farmlands, the wetland must now be artificially flooded via an aqueduct, and even then only part of it receives water. Thus, water input varies greatly, both seasonally (winter rains) and annually

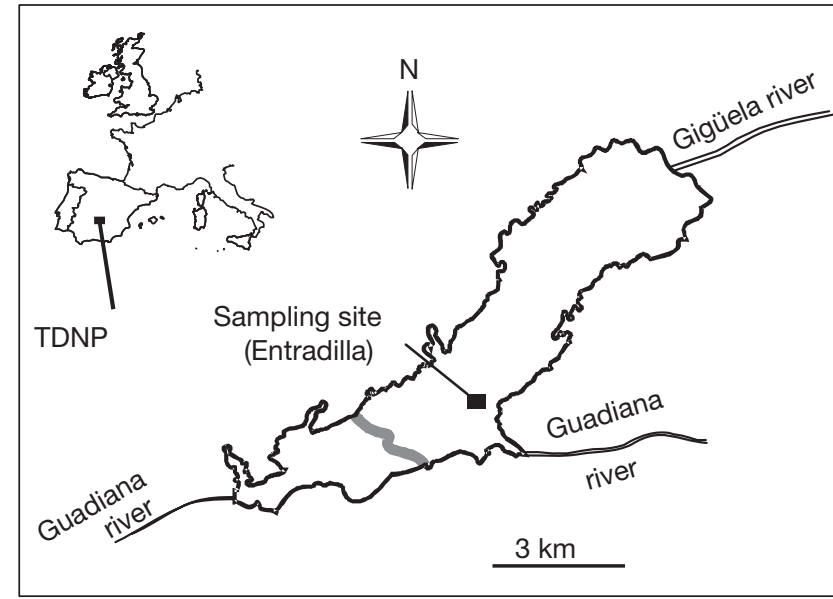

Fig. 1. Location of Tablas de Daimiel National Park (TDNP) wetland, $39^{\circ} 08^{\prime} \mathrm{N}, 3^{\circ} 43^{\prime} \mathrm{W}$

(Sanchez-Carrillo \& Alvarez-Cobelas 2001). TDNP has been monitored from 1992 to the present (AlvarezCobelas et al. 2001) and has been described as a eutrophic (OECD 1982) and turbid ecosystem that covers less than $15 \mathrm{~km}^{2}$.

During the experimental period, TDNP water $\mathrm{pH}$ was around 7 to 9 . Water sulphate concentrations were around $4 \mathrm{~g} \mathrm{l}^{-1}$. The minimum and maximum concentrations of total nitrogen varied between 0.2 and $3.7 \mathrm{mg}$ $\mathrm{l}^{-1}$. Total phosphorus ranged between a minimum of $0.015 \mathrm{mg} \mathrm{l}^{-1}$ and a maximum of $0.123 \mathrm{mg} \mathrm{l}^{-1}$. Chlorophyll (chl) a concentrations ranged between 6 and $26 \mu \mathrm{g} \mathrm{l}^{-1}$. Phytoplankton biomass registered a minimum of $0.03 \mathrm{mg}$ wet weight (ww) $\mathrm{l}^{-1}$ and a maximum of $95 \mathrm{mg} \mathrm{ww} \mathrm{l}^{-1}$. Cryptophytes and diatoms were the most abundant algae, with chlorophytes and Cyanobacteria as co-dominant groups (Rojo et al. 2000). Total zooplankton biomass fluctuated appreciably throughout the annual cycle (from undetectable levels to $280 \mathrm{mg} \mathrm{ww} \mathrm{l}^{-1}$ ). Ciliates were among the most important components of zooplankton in terms of biomass; the omnivorous copepod Acanthocyclops robustus Sars was the largest zooplankter for most of the year, while cladocerans appeared and peaked only in spring (Ortega-Mayagoitia et al. 2000). The main area of the wetland is covered by emerging macrophytic reed beds of Phragmites australis (Cav) Trin. ex Steud. and saw grass Cladium mariscus. Artificially introduced fish, comprising carp Cyprinus carpio (L.), mosquitofish Gambusia holbrooki (Gir.) and pumpkinseed Lepomis gibbosus (L.), have displaced wetland native species. The flooded areas are covered by dense beds of charophytes (mainly Chara spp.).

Samples for bacterial diversity analyses were taken in Entradilla (Fig. 1), which is practically the only part of the wetland that, at present, remains flooded throughout the year. Entradilla is a fairly constantly isolated 
brackish pond (conductivity 2 to $12 \mathrm{mS} \mathrm{cm}^{-1}$ ) surrounded by a reed fringe, 50 to $70 \mathrm{~cm}$ deep, with a high concentration of dissolved organic carbon (4 to $13 \mathrm{mg}$ $\mathrm{l}^{-1}$ ). Sampling was performed at noon on 13 June 2007 , as a representative month of the dry hydrological period.

Sampling procedures. Two litres of water (water sample: 'W') were collected in a sterile plastic flask, taking care not to disturb the water column by submerging the flask from the surface down. A sediment sample was collected by using a sterile plastic core to penetrate the sediment to a depth of about $10 \mathrm{~cm}$. About $3 \mathrm{~g}$ (1 cm thick layers) were taken from the top (first) centimetre of the sediment (the water-sediment interface was called the upper sediment sample: 'US') and bottom layers $(5 \mathrm{~cm}$ deep in the sediment, lower sediment sample: 'LS'). A third kind of sample was collected on a microbial mat covered mainly by benthic algae (diatoms), Cyanobacteria and remains of emergent vegetation that was located on the 'beach' or shore surrounding the water (biofilm sample: 'B'). A slice of this biofilm, rich in remains of vegetation, was collected with a sterile spatula. About $3 \mathrm{~g}$ were recovered from the bottom part of the biofilm layer. Immediately after sampling, all samples were stored at $4{ }^{\circ} \mathrm{C}$ in the dark until processed in the laboratory within the following $12 \mathrm{~h}$. In the laboratory, the entire volume of the water sample was prefiltered through a $3 \mu \mathrm{m}$ filter (Millipore). The filtered water was concentrated in a $0.2 \mu \mathrm{m}$ Sterivex filter (Millipore) for subsequent lysis and DNA extraction steps.

Total bacterial numbers and limnological variables. For bacterial counts, water samples $(1 \mathrm{ml})$ were stained in the dark with 4', 6-diamidino-2-phenylindole (DAPI, Sigma-Aldrich) following standard procedures (Porter \& Feig 1980). A minimum of 10 microscopy fields and around 1000 cells sample ${ }^{-1}$ were counted for each sample. Slides were observed at a total magnification of $1000 \times$. For each sample, random microscope fields were captured as images with a digital camera (Nikon DXM1200F). Counts were made on a computer screen. The solid samples (US, LS and B; $0.1 \mathrm{~cm}^{3}$ sample) were put into sterile plastic vials ( $10 \mathrm{ml}$ capacity) with $7.9 \mathrm{ml}$ of particle-free water, mixed vigorously for $10 \mathrm{~min}$ with a shaker (Falc Mix 20) at $1500 \mathrm{rpm}$ and sonicated for $10 \mathrm{~min}$. The sonic bath (Elmasonic S 30H) was filled with ice water to prevent the cells from overheating. After sonication, the tubes were shaken again and allowed to settle for $5 \mathrm{~min}$ before the supernatant was collected. The supernatant was treated for bacterial enumeration (staining, counting) as described above for the water samples. Bacterial cell counts were transformed into biomass by estimating cellular biovolumes and assuming a bacterial cellular density of $1 \mathrm{~g} \mathrm{~cm}^{-3}$ (Linley et al. 1983).

Water temperature, $\mathrm{pH}$, conductivity and dissolved oxygen values were measured in situ with the appropriate sensors. Total phosphorus and nitrogen concentrations were determined following standard methods (APHA-AWWA-WEF 2005).

DNA extraction. DNA from water samples was extracted directly from Sterivex filters (Steward et al. 2004). The water was purged by insufflating air into the Sterivex filters, and $1.8 \mathrm{ml}$ of STE buffer $(20 \%$ sucrose, $50 \mathrm{mM}$ Tris-HCl, $50 \mathrm{mM}$ EDTA) was added. Lysis was performed by adding $100 \mu \mathrm{l}$ of $50 \mathrm{mg} \mathrm{ml}^{-1}$ lysozyme (Roche) to the samples and incubating them at room temperature for $1 \mathrm{~h}$. Then $80 \mu \mathrm{l}$ of $10 \mathrm{mg} \mathrm{ml}^{-1}$ Proteinase K (Sigma-Aldrich) were added and samples incubated for $1 \mathrm{~h}$ at $60^{\circ} \mathrm{C}$. The complete lysates were aspirated from the inlet of the Sterivex filter with a syringe and cleaned by phenol::chloroform, phenol:: chloroform::isoamyl alcohol extraction. The DNA was then purified by adding ammonium acetate followed by isopropanol precipitation at $-20^{\circ} \mathrm{C}$ overnight. The samples were then centrifuged at $15700 \times g$ for $30 \mathrm{~min}$ and the pellets were washed in $70 \%$ ethanol. The pellets were air dried and resuspended in TE (10 mMol TrisHCL:1 mMol EDTA) buffer.

Sediment and biofilm (US, LS and B) DNA were extracted and purified with the PowerSoil ${ }^{\mathrm{TM}}$ DNA Kit (MoBio) following the manufacturer's instructions.

PCR conditions, cloning and sequencing. 16S rDNA genes were amplified by polymerase chain reaction (PCR) using universal eubacterial forward and reverse primers 27F (5'-AGAGTTTGATYMTGGCTCAG-3') and 1492R (5'-TACGGYTACCTTGTTACGACT-3') (Lane 1991, Yakimov et al. 2004). The PCR conditions were: initial denaturing step at $95^{\circ} \mathrm{C}$ (4 min) followed by 30 cycles of denaturing, annealing and an extension of $95^{\circ} \mathrm{C}(30 \mathrm{~s}), 53^{\circ} \mathrm{C}(30 \mathrm{~s}), 74^{\circ} \mathrm{C}(1 \mathrm{~min})$, and a final extension step at $74^{\circ} \mathrm{C}$ (10 min). The PCR products were purified by ammonium acetate precipitation (0.1 vol ammonium acetate $7.5 \mathrm{M}, 2 \mathrm{vol}$ absolute ethanol) and washed in water. The products were transformed by electroporation in the TOPO-XL vector of the TOPOXL PCR cloning kit (Invitrogen), according to the manufacturer's instructions. Transformed cells were plated on Luria-Bertani (LB) medium (10 $\mathrm{g} \mathrm{l}^{-1}$ tryptone; $5 \mathrm{~g} \mathrm{l}^{-1}$ yeast extract; $10 \mathrm{~g} \mathrm{l}^{-1} \mathrm{NaCl}_{\text {; }}$ agar $1 \%$ ) agar plates with kanamycin (final concentration $50 \mu \mathrm{g} \mathrm{ml} \mathrm{m}^{-1}$ ) for screening. Positive colonies were picked and grown in LB broth for plasmid extraction by a Millipore Plasmid MiniPrep $_{96}$ kit. Plasmid extraction was automated by using a MULTIPROBE II-Robot Liquid Handling System (Packard). Purified plasmids were sequenced with the ABI BigDye Terminator Cycle Sequencing system kit V3.1 (PE Applied Biosystems) using M13 forward and reverse primers. Almost all clones were sequenced in both directions and were overlapped to obtain the complete 16S rDNA gene sequence. 
Sequence analysis. In total, 703 clones were sequenced with an average length of 1215 nucleotides. Each electropherogram was manually checked with the Geneious suite (v3.7.1). No chimeras were detected using the Chimera Check function from the Ribosomal Database Project (RDP). Taxonomy relationships for each sequence were attributed by carrying out similarity searches against a curated dataset of reference sequences from the RDP (Cole et al. 2009). From an original set of about 350000 sequences, we obtained a nonredundant dataset by performing a clustering at $99 \%$ of similarity with the CD-HIT program (Li \& Godzik 2006), generating a dataset of about 65000 sequences with known taxonomic affiliation. A local BLAST search of a whole TDNP sequence dataset (Altschul et al. 1990) was performed against this restricted dataset from the RDP database. Best match sequences were used to assign a minimal but confident taxonomical position to each TDNP sequence. In the event that the taxonomical position was not clear, we used upper unambiguous hierarchical assignation (at the level of phylum, class, order, family, genus), leaving the lower level as 'unidentified'. Clusters at several levels of similarity were obtained with 'CD-HIT' (see 'Results').

Rarefaction analysis was carried out with paleontological statistics software (PAST v 1.19; Hammer et al. 2001). PAST software was also used to calculate several diversity indices, such as Dominance, Shannon, and Equitability. The Dominance index was calculated as $D=\Sigma\left(\mathrm{n}_{\mathrm{i}} / \mathrm{n}\right)^{2}$ where $\mathrm{n}_{\mathrm{i}}$ is the number of individuals of taxon $\mathrm{i}$, and $\mathrm{n}$ is the total number of individuals. The Shannon information index was calculated as $H=-\Sigma$ $\mathrm{n}_{\mathrm{i}} / \mathrm{n} \ln \left(\mathrm{n}_{\mathrm{i}} / \mathrm{n}\right)$ (Shannon \& Weaver 1963), and the Equitability index was calculated as $J=H / H_{\text {max }}$ where $H$ is the Shannon information index and $H_{\max }=\ln (S)$, where $S$ is the richness or number of taxa.

Sequence alignments were obtained by the RDP online applications and, when necessary, manually checked and corrected using the BioEdit Sequence Alignment Editor program version 5.09 (www.mbio. ncsu.edu/BioEdit/bioedit.html; Hall 1998). Phylogenetic trees were constructed following Minimum Evolutionary methods (MEGA software version 4; Kumar et al. 2008). Bootstrap tests based on 500 replicates were obtained. All sequences are freely accessible in GenBank (www.ncbi.nlm.nih.gov/Genbank/index. html) under accession numbers FJ516762 to FJ517139.

\section{RESULTS}

\section{Limnological variables and total bacterial numbers}

TDNP waters were well oxygenated on the sampling date and water $\mathrm{pH}$ was around 7.5 (Table 1). Total
Table 1. Values of the main limnological variables measured on the sampling date in June 2007

\begin{tabular}{|lc|}
\hline Variable & Value \\
\hline Temperature $\left({ }^{\circ} \mathrm{C}\right)$ & 21.8 \\
Conductivity $\left(\mathrm{mS} \mathrm{cm}^{-1}\right)$ & 9.1 \\
Dissolved oxygen $\left(\mathrm{mg} \mathrm{l}^{-1}\right)$ & 10.8 \\
$\mathrm{pH}$ & 7.47 \\
Total nitrogen $\left(\mathrm{mg} \mathrm{N}^{-1}\right)$ & 1.97 \\
Total phosphorus $\left(\mathrm{mg} \mathrm{P} \mathrm{l}^{-1}\right)$ & 0.014 \\
Planktonic chlorophyll a $\left(\mu \mathrm{g} \mathrm{l}^{-1}\right)$ & 6.5 \\
Secchi depth $(\mathrm{m})$ & 0.5 \\
\hline
\end{tabular}

phosphorus concentration was close to the lowest limit registered for TDNP for previous years, whereas total nitrogen concentration was closer to the highest values reported for this wetland. The total bacterial density in the W sample was $2.3 \times 10^{6}$ cells ml $^{-1}\left( \pm 0.03 \times 10^{6}\right.$ cells $\mathrm{ml}^{-1}, 95 \% \mathrm{CI}$ ), representing a biomass of $0.1 \mu \mathrm{g} \mathrm{ww}$ $\mathrm{ml}^{-1}$. In US and LS samples, the bacterial densities were $1.2 \pm 0.11 \times 10^{6}$ and $2.3 \pm 0.14 \times 10^{6}$ cells $\mathrm{mg}^{-1}$ dry weight $(\mathrm{dw})$ sediment, respectively. The corresponding biomass was 0.06 and $0.11 \mu \mathrm{g} \mathrm{ww} \mathrm{mg}^{-1} \mathrm{dw}$ sediment, respectively). Finally, total bacterial density was the highest in the B sample with $2.8 \pm 0.09 \times 10^{6}$ cells $\mathrm{mg}^{-1} \mathrm{dw}\left(0.14 \mu \mathrm{g} w \mathrm{w} \mathrm{mg}^{-1} \mathrm{dw}\right.$ sediment $)$.

\section{Diversity indices and rarefaction}

The 4 samples harboured high bacterial diversity. According to the 'order' level described in 'Material and methods', 30, 16, 23 and 19 taxa were identified for W, US, LS and B samples, respectively. In general, the dominance values were quite low at all clustering levels for all samples, indicating high diversity in TDNP. The Shannon index, calculated on clusters obtained at $97 \%$ of similarity (superscript), shows the following upward gradient for diversity, LS: $3.2^{97}<$ B: $3.6^{97}<$ US: $4.3^{97}<\mathrm{W}: 4.9^{97}$ (Table 2). Not only did the W sample show the most diverse bacterial community, but also the most evenly distributed one $\left(J^{97}=0.95\right.$; Table 2$)$.

The rarefaction analysis for the 4 samples (Fig. 2) shows that all curves are saturated at the order level. However, on observing the distribution of closely related taxa (i.e. at $97 \%$ of similarity clustering) the curves do not reach a plateau, and those corresponding to LS and B samples seem to have smaller slopes.

\section{Diversity distribution}

Fig. 3 shows the percentage distribution of clones at phylum, class and family levels. Most of the retrieved clones belong to the phylum Proteobacteria: 46, 41, 72, 
Table 2. Diversity indices applied to sequence abundances for operational taxonomic units (OTUs) calculated at the order level and $97 \%$ of clustering similarity. For each sample, the labels in superscripts describe the phylogenetic level or the similarity threshold (\%) used to make the clusters

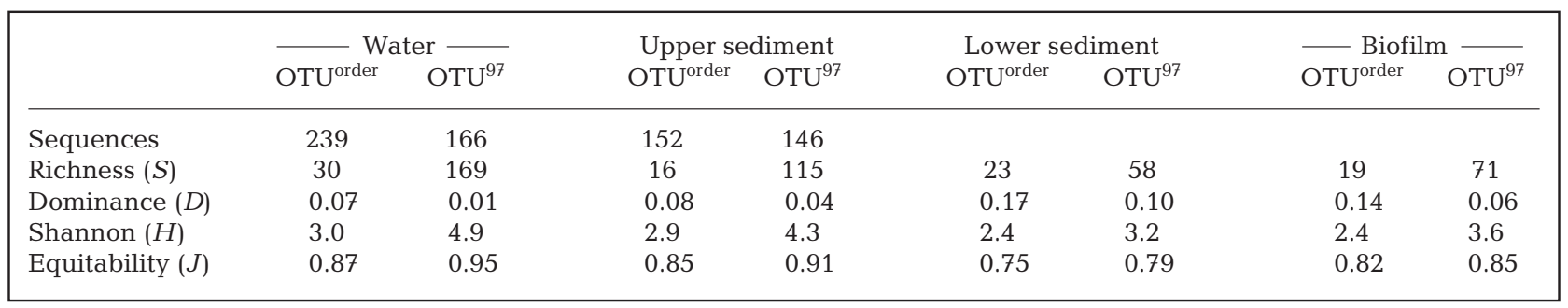

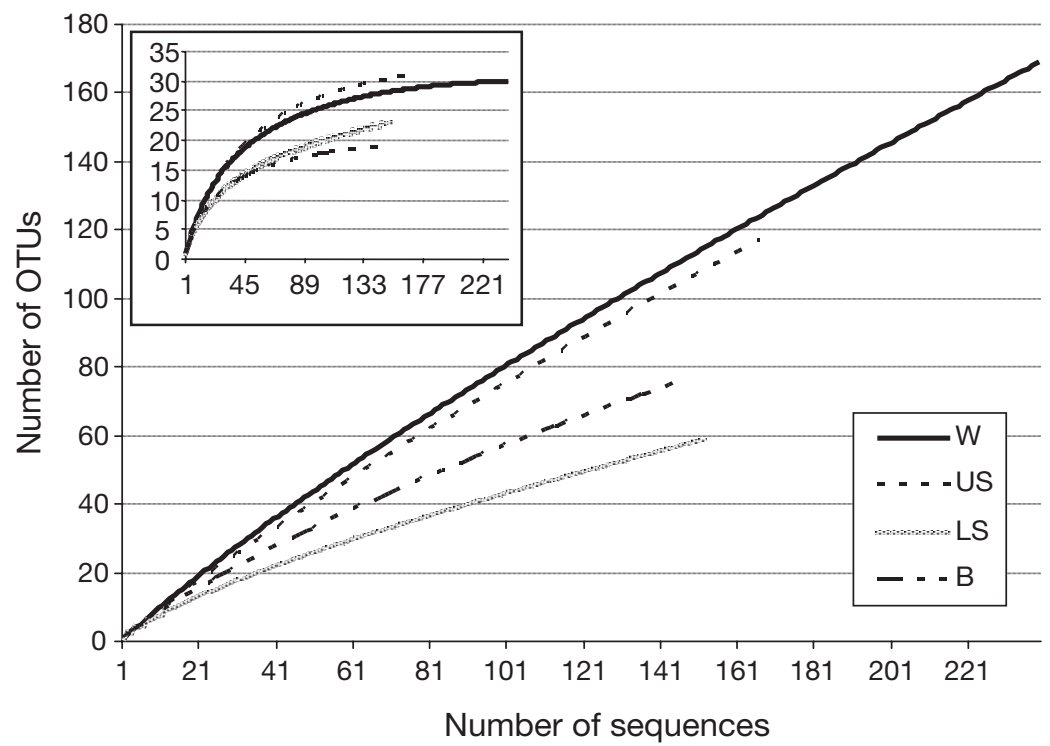

Fig. 2. Rarefaction curves, calculated at the order level of clustering (inset) and at $97 \%$ of clustering similarity. The lines describe the samples of water (W), upper sediment (US), lower sediment (LS) and biofilm (B). OTU: operational taxonomic unit

and $66 \%$ for W, US, LS and B samples, respectively (described in detail in the following section). Sequences belonging to Bacteroidetes were the second most abundant with $14 \%$ (W), $14 \%$ (US), $10 \%$ (LS) and $14 \%$ (B). The Cyanobacteria phylum was quite abundant in the US sample (19\%), while it was found at only 5, 5 and $2 \%$, in W, LS and B samples, respectively. Chloroflexi and Actinobacteria sequences represented between 1 and $9 \%$ of each sample.

Less abundant phyla showed an uneven distribution: clones of the phyla Acidobacteria were found only in W and US samples at $7.1 \%$ (20 clones) and 1.8\% (3 clones), respectively. Similarly, Nitrospira, with 3.4 and $1.2 \%$ (8 and 2 clones), Spirochaetes with 1.2 and $1.8 \%$ (3 and 3 clones), as well as Firmicutes, Deferribacteres and WS3, were only retrieved from W and US samples.

Classes of Bacteroidetes, Sphingobacteria, Planctomycetacia, Proteobacteria (all but Epsilonproteobacteria) and Verrucomicrobia were retrieved from all the samples at variable percentages.
Figs. S1 to S3 in the supplement (available at www.int-res.com/articles/ suppl/a059p033_app.pdf) show the taxonomical positions of representative clones for each cluster together with their closest RDP best match reference sequences.

\section{Distribution of Proteobacteria}

Within the Proteobacteria, the classes Alpha- and Betaproteobacteria were much more abundant in LS and B samples (Fig. 3). Epsilonproteobacteria were less abundant (around 1\%) and were found only in the LS and B samples. Conversely, classes Gamma- and Deltaproteobacteria were more abundant in the W and US samples. Less than $1 \%$ of unclassified Proteobacteria sequences were retrieved from W, US and B samples (Fig. 3). Although all Proteobacteria classes were represented by sequences found in TDNP, some families were only found in some TDNP habitats.

At the family level, the most abundant families of Alphaproteobacteria were the Rhodobacteraceae (LS: $10.5 \%$ and B: $13 \%$ of clones) and Sphingomonadaceae (LS: $7.2 \%$, B: $6.9 \%$ ). Other minor groups of Alphaproteobacteria were retrieved in all 4 samples (Fig. 3, Fig. S4). A similar distribution was observed for Burkholderiaceae, the most-represented family of Betaproteobacteria (LS: $28 \%$, B: $21 \%$ ). The family Comamonadaceae was also found mainly in LS (6\%) and B (5\%) samples. Hydrogenophilaceae were only found in W and US (4 and 2\%, respectively; Fig. S5). Within Gammaproteobacteria, Chromatiaceae was the most abundant family, with clones present only in the $\mathrm{W}$ and the LS samples. Other less abundant families were found mainly in the LS samples (Fig. S6). Finally, a subset of unidentified Gammaproteobacteria was found from W, US, LS and B samples, at percentages of $8.0,8.4,6.7$ and $3.4 \%(10,8,5$ and 5 clones $)$, re- 


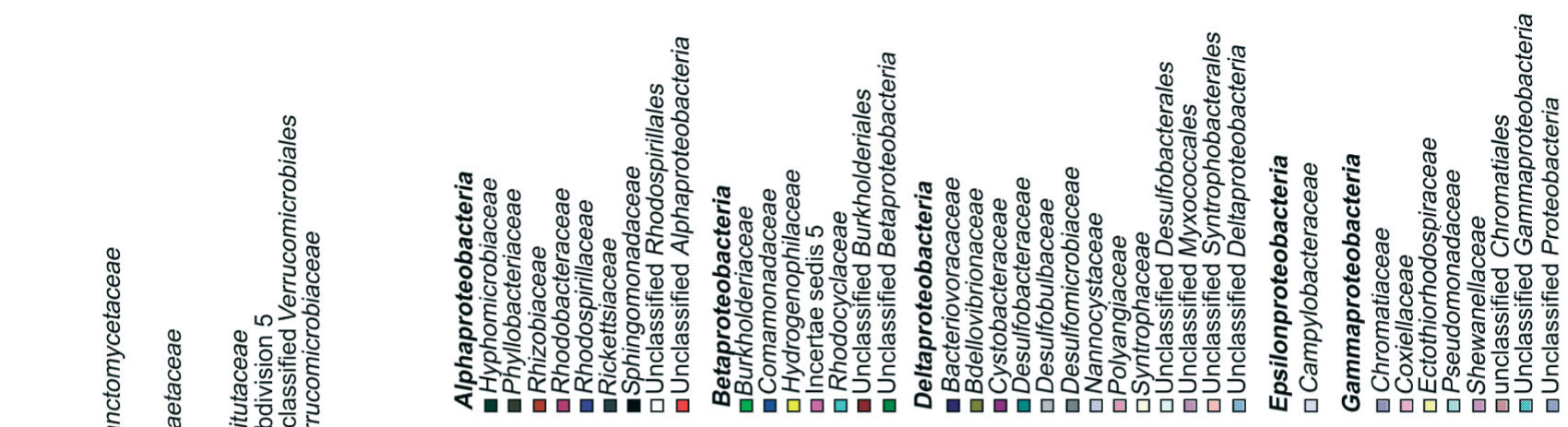

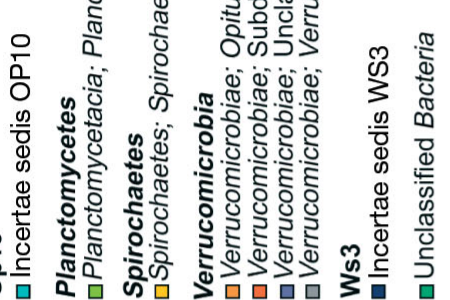
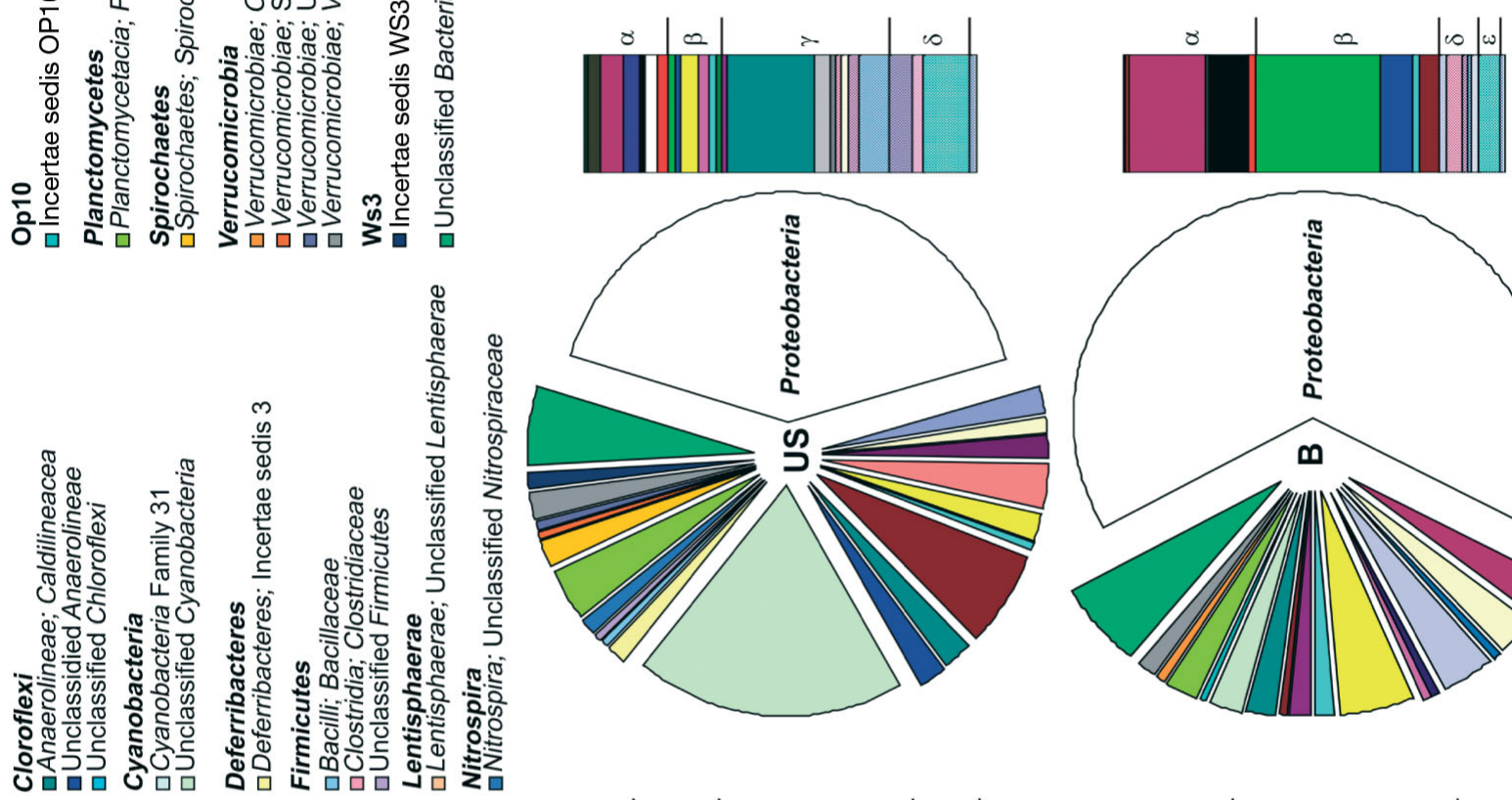

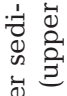

월 च

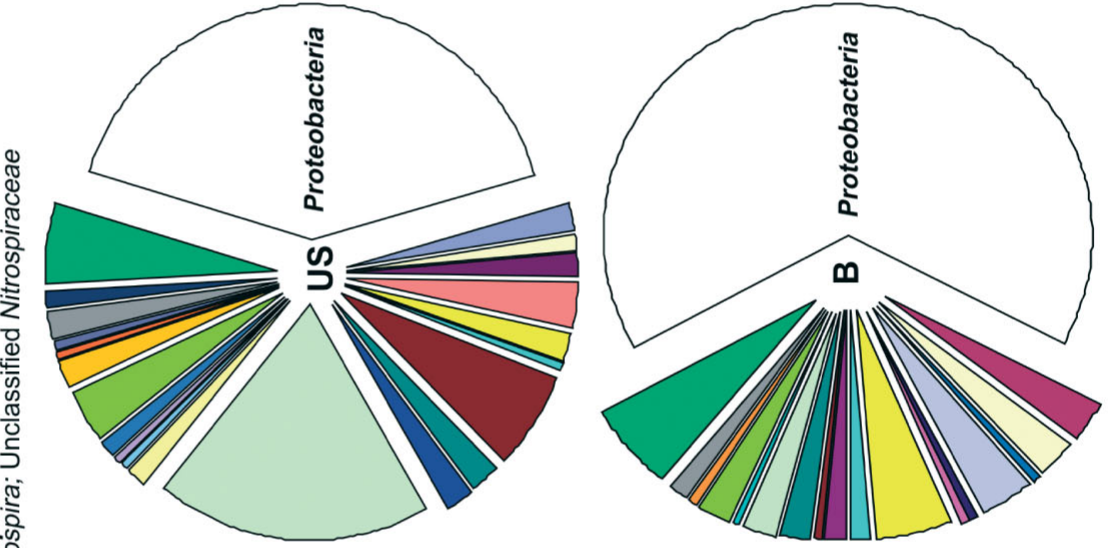

串究
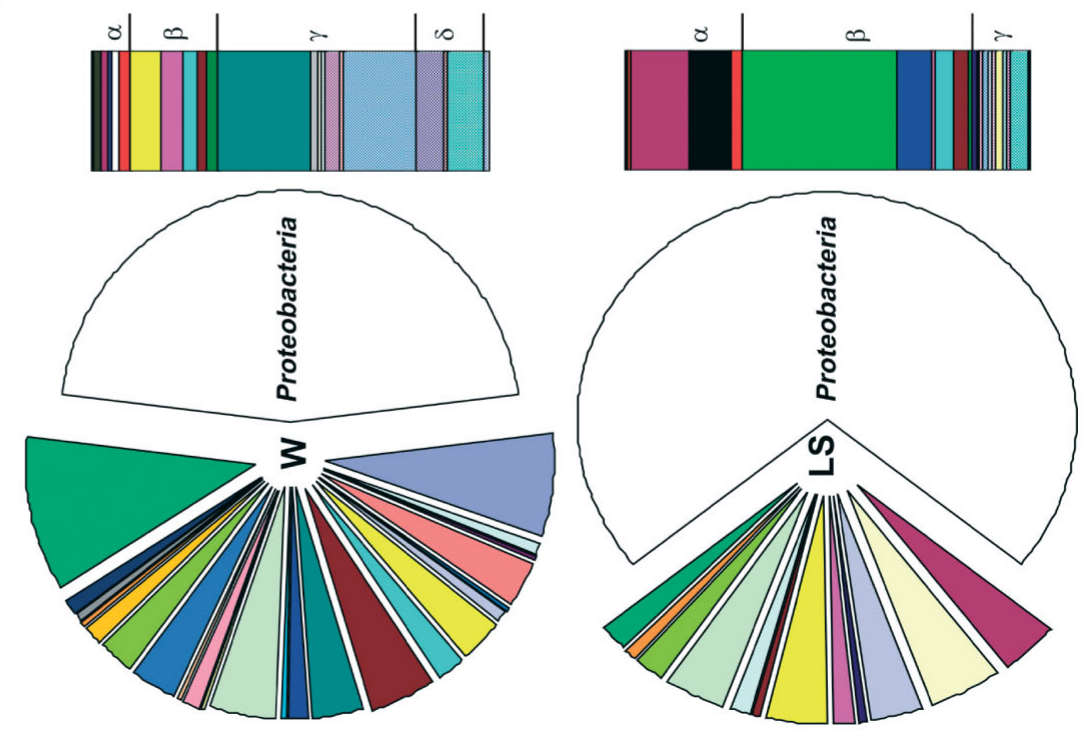

空

3 풍

옹요

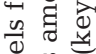

过

记

䓒 을

可

घี

चี

坖

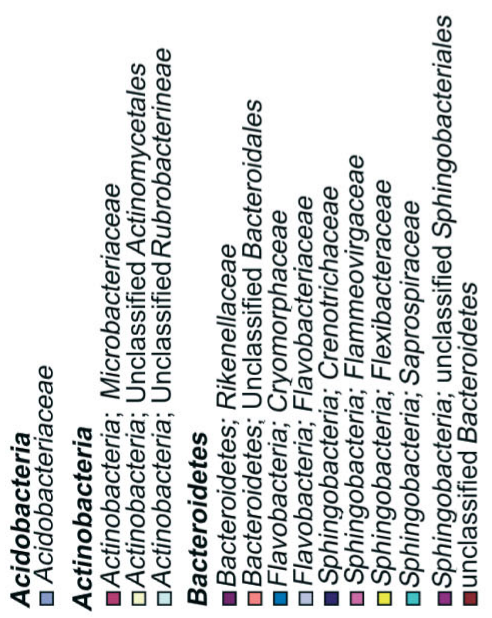

g)

至, 范

동

ซี हㅕㅇ

की

胥

可

记

을 छ

규워

落

焉

的䓈 


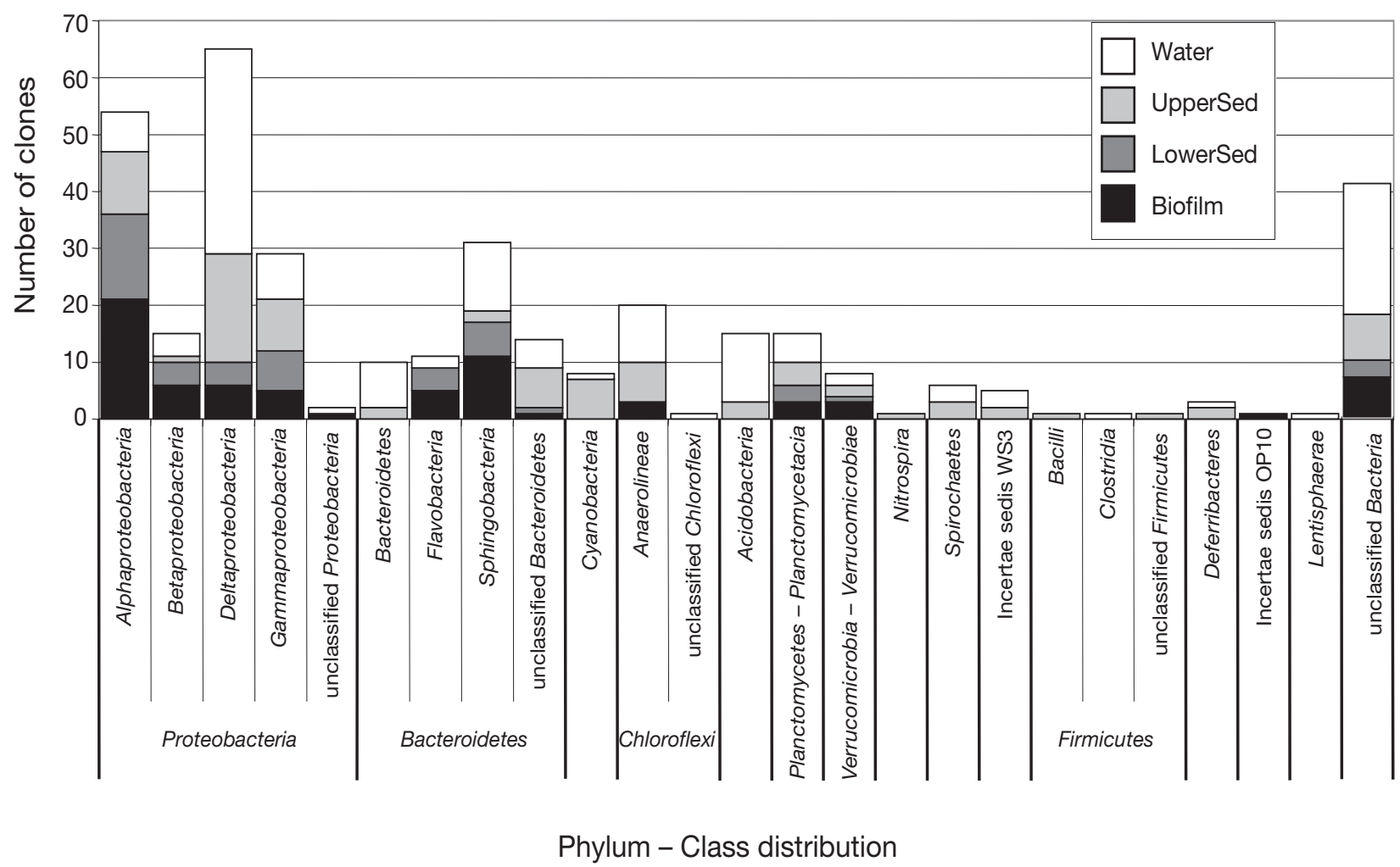

Fig. 4. Clone distribution at the phylum and class taxonomic level of 'new' phylogroups. 'New' phylogroup clones were considered when the best match had a similarity value below $97 \%$. Bars subdivided to show sample origin (sed: sediment)

spectively (Fig. 4, Fig. S7 in the supplement). Within the Deltaproteobacteria, Desulfobacteraceae was the most abundant family, found only in the W (11\%) and the US (9\%) samples. Only 3 clones belonging to Epsilonproteobacteria (family Campylobacteraceae) were identified in B (2) and LS (1) samples.

\section{New phylogroups}

For 359 of the 703 clones analysed, the closest database match was less than $97 \%$ similar. By applying the same clustering criterion to these 359 clones, we defined 265 new phylogroups, with the following distribution: 124 operational taxonomic units calculated at $97 \%$ of clustering similarity $\left(\mathrm{OTUS}^{97}\right)$ in the W sample; 81 OTUs $^{97}$ in the US sample; 35 OTUs $^{97}$ in the LS sample; and $55 \mathrm{OTUs}^{97}$ in the B sample. Fig. 4 shows the distribution of the new phylogroups, at the levels of phylum and class.

The Proteobacteria included 107 new phylogroups, with the following class distribution: Delta (48) > Alpha (37) > Gamma (14) > Beta (6) > Unclassified (2) (Fig. 5). W and US samples had the highest number of new phylogroups belonging to the Deltaproteobacteria (30 and 16, respectively). Of these, 15 and 7 phylogroups, respectively, belonged to the family Desulfobacteraceae. The rest belonged to different orders of Deltaproteobacteria, such as Bdellovibrionales, Myхоcoccales and Syntrophobacterales. Regarding Alphaproteobacteria, the highest number (16 clusters) of new phylogroups belonged to the family Rhodobacteraceae. New, less abundant phylogroups belonging to the Gammaproteobacteria were found almost uniformly distributed among all 4 samples, but remained unidentified below the class level. Within Betaproteobacteria, unidentified clusters were found belonging to the order Burkholderiales and Rhodocyclales.

In the phylum Bacteroidetes, 42 new phylogroups distributed among the 4 samples were found (Fig. 4). The distribution within classes is as follows: Bacteroidetes was predominant in W (7) and B (2) samples; Flavobacteria were found in B (4) and LS (3) samples; and Sphingobacteria were found in W (6), LS (3) and B (9) samples.

Finally, 85 less abundant new phylogroups were found within other phyla (Fig. 4), such as Chloroflexi, Deferribacteres, Cyanobacteria, Firmicutes, Lentisphaerae, Nitrospira, Spirochaetes, Verrucomicrobia, as well as other unidentified bacteria. 


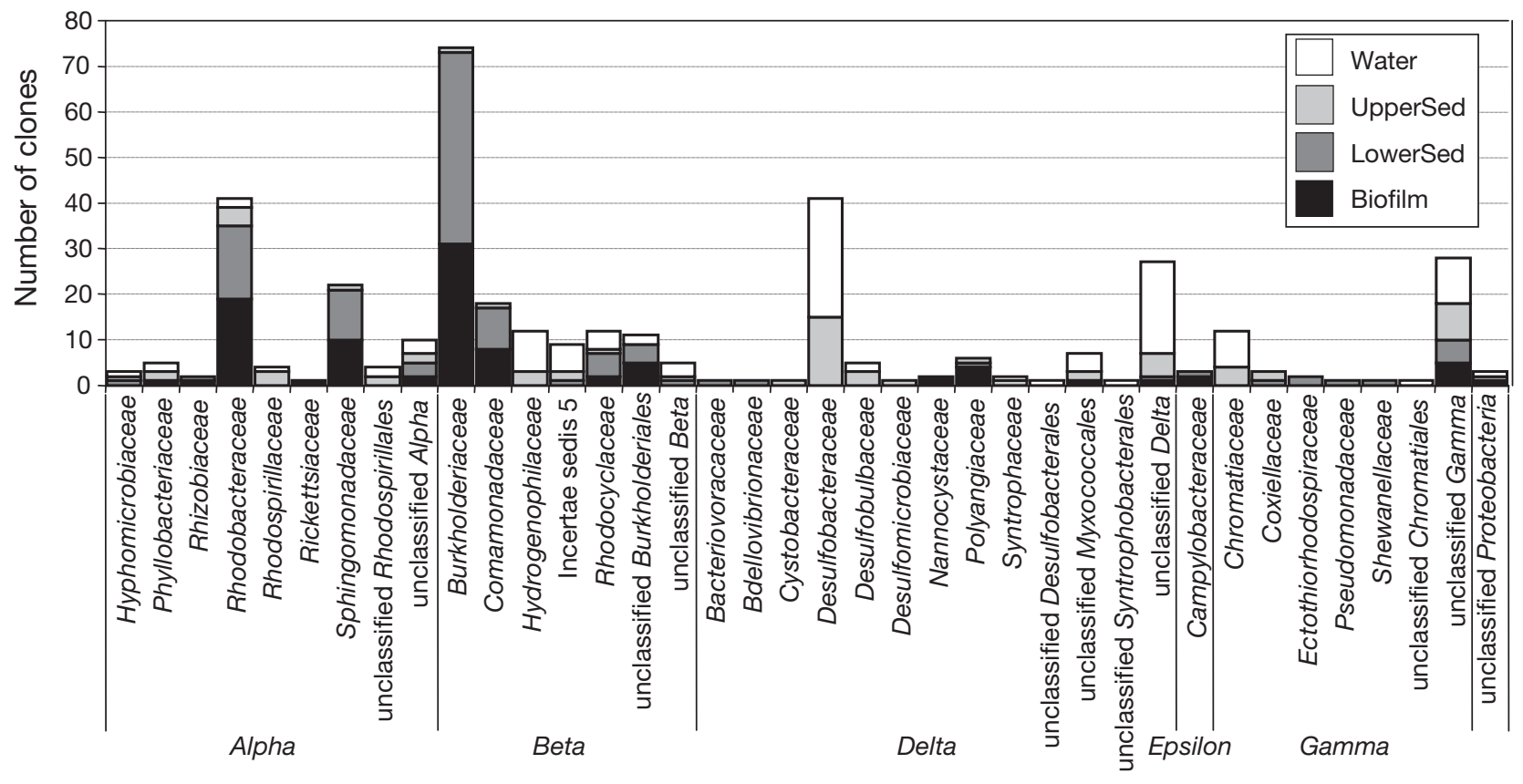

Class - Family distribution

Fig. 5. Clone distribution of 'new' phylogroups within the phylum of Proteobacteria. 'New' phylogroup clones were considered when the best match had a similarity value below $97 \%$. Bars subdivided to show sample origin (sed: sediment)

\section{DISCUSSION}

\section{Overall phylogenetic bacterial diversity}

Total prokaryotic densities found in TDNP waters were in the range of bacterial abundances found in other wetlands (for example, the riverine wetland described by Farnell-Jackson \& Ward 2003). Gene sequences belonging to 13 phyla from 27 of the cultured Eubacteria were retrieved from the 4 TDNP habitats. In addition, sequences belonging to uncultivated candidate divisions OP10 and WS3 were obtained, as well as many sequences that could not be affiliated to any known sequence with sufficient similarity. Although many bacteria are represented, the true bacterial diversity may still be underestimated, as indicated by the rarefaction curves, which do not reach a diversity plateau, especially for W and US samples. Despite this, the eubacterial diversity (measured by the Shannon index) in W and US samples obtained in TDNP ( $H=4.9$ and 4.4, respectively) is higher than in other types of environments, where bacterial diversity was described by similar methodology, for example the monimolimnion of Lake Pavin in France $(H=3.1$ to 3.6; Lehours et al. 2007) or the water column and watersediment interface of a freshwater pond, also in France (4.0 and 3.3, respectively; Briée et al. 2007). In the Korean Woopo wetland, Baik et al. (2008) reported a value of $H=4.4$. Ahn et al. (2007) reported $H$ values of
2.9 to 3.1 for soil microbial communities in treated microcosm wetlands. On the other hand, bacterial diversity $(H=3.2)$ in TDNP sediment is close to the diversity described for soils $(H=3.3$ to 4.0$)$ in Northern Victoria Land (Antarctica; Niederberger et al. 2008) or the sediments of the pond studied by Briée et al. (2007; $H=3.9$ ). In comparison with marine habitats, Zaballos et al. (2006) reported maximum $H$ values of 4.02 for the Ionian Sea.

The 4 samples analysed for bacterial diversity belong to 4 types of environment, and the bacterial clone libraries found were different, which would indicate spatial heterogeneity of the microbial community in TDNP. W and US samples were the richest in bacterial phyla, and some of them were exclusive to these 2 environments. Conversely, the LS and B samples contained no exclusive phyla (with the exception of the OP10 group sequences, found in low abundance); however, exclusive families were found in each environment. Our findings could support the idea that there is environmental selection of organisms with suitable physiology (Niederberger et al. 2008). W and US samples were the most similar, probably because the US sample represents the interface between the water column and the sediment and many kinds of bacteria can share these 2 environments (Stevens et al. 2005). Moreover, in a shallow environment like TDNP, resuspension of surface sediment and mixing with the water column is likely to occur. The fact that bacterial 
diversity was highest in the $\mathrm{W}$ sample is probably due to the influence of the submerged vegetation, among other factors. In the Entradilla sampling station, dense meadows of charophytes (Chara hispida) grow all year round, and many other organisms (e.g. epiphytic algae, zooplankters, macroinvertebrates, fish) associated with them can provide nutrient sources, attachment surfaces and microenvironments for certain types of microorganisms (Basu et al. 2000).

Phylotypes belonging to Chloroflexi were found both in plankton and biofilm samples in moderate abundance. Chloroflexi are anoxygenic phototrophic filamentous bacteria, which can be quite thermophilic and are frequently encountered in hot springs, although environmental surveys have also revealed many diverse phylotypes of these green non-sulphur bacteria in anoxic zones of stratified freshwater systems (Gich et al. 2001). More recently, Shrestha et al. (2009) detected expressed sequence tags affiliated with Chloroflexi in both oxic and anoxic paddy soils. One TDNP sequence from the W sample was found to be related to an uncultured Dehalococcoides species.

Cyanobacteria clone sequences were more abundant in US than in the other 3 samples. This is not surprising because at the water-sediment interface there are higher concentrations of Cyanobacteria, including both those settled from the water column $\left(10^{2}\right.$ ind. $\left.\mathrm{ml}^{-1}\right)$ and those with benthic habits. It is worth mentioning that gene sequences of chloroplasts belonging to eukaryotic algae are also included in this phylum (Garrity et al. 2005), as a distinct and highly diverse subgroup. Thus, some chloroplast sequences retrieved from TDNP match with those of some diatom species. A chloroplast sequence that was very similar to the Chara vulgaris sequence in the database was also retrieved from the TDNP US sample. This can be explained by the presence of Chara hispida meadows in Entradilla waters. Some non-chloroplast TDNP Cyanobacteria sequences were affiliated with those of the genera Lyngbya, Halomicronema and Leptolyngbia. Other sequences were affiliated with unclassified and uncultured cyanobacterial sequences in the database.

A particular case is that of Actinobacteria, known to be an important ecological player in brackish water (Holmfeldt et al. 2009); however, sequences belonging to this group were scarcely found in TDNP libraries. In $\mathrm{W}$ and US, Actinobacteria-related sequences do not correspond closely with cultured species, similar to what was found in Lake Taihu, where Actinobacteria were not found at eutrophied sites (Liu et al. 2009). Similarly, sequences of the phylum Acidobacteria were also found only in W and US. Briée et al. (2007) found acidobacterial phylotypes in a freshwater pond, both in water and sediments and, conversely to TDNP, they were much more frequent in sediment samples.
Presence of the phylum Planctomycetes was not high in TDNP libraries, but their abundance was quite similar in each sample. Some Planctomycetes species are facultative aerobic chemoorganotrophs, which grow by fermentation or respiration, although others are strict anaerobic autotrophs that carry out the anaerobic oxidation of ammonia using nitrite (anammox). Since the TDNP environments under study differ in terms of redox conditions, species with aerobic and anaerobic metabolisms are likely to occur.

In TDNP, sequences of the phylum Verrucomicrobia were retrieved from all environments although in low abundance. Known Verrucomicrobia species are able to ferment a variety of sugars (aerobic or facultatively aerobic chemoheterotrophic bacteria), and hence they may participate in the degradation of organic material in TDNP. One TDNP sequence from the B sample is very similar to that of Alterococcus agarolyticus. Another sequence, also from $B$, is distantly related to the genus Kocuria. Two species of this genus are $K$. palustris and $K$. rhizophila, isolated from the rhizoplane of the narrow leaved cattail Typha angustifolia (Kovacs et al. 1999). The TDNP B sample was taken from an area covered by similar emergent aquatic vegetation.

Most genera in the phylum Nitrospira are aerobic chemolithotrophs, including nitrifiers and dissimilatory sulphate reducers. This fits well with the kind of habitat in which TDNP Nitrospira sequences were found in terms of oxygen availability (only water and watersediment interface). Sequences of Spirochaetes, a phylum that includes chemoorganotrophic, anaerobic, microaerophilic, facultative anaerobic or aerobic bacteria, were retrieved only from W and US. One sequence retrieved from $\mathrm{W}$ matched an uncultured species of the genus Spirochaeta, and another from US with an endosymbiont spirochete. In other freshwater water-bodies, Spirochaetes were also found in plankton and sediments (Briée et al. 2007).

The phenotypically varied Firmicutes phylum was poorly represented in TDNP libraries, with 2 of the 3 classes of this phylum: Bacilli in US and Clostridia in W, whose sequences are close to those of uncultured soil bacteria. Sequences belonging to the phylum Deferribacteres were found only in W and US samples. Just 1 clone affiliated to Lentisphaerae was retrieved from TDNP water. This relatively new phylum is composed of bacteria from marine and anaerobic terrestrial environments, but other isolates are strictly aerobic, chemoheterotrophic, and facultatively oligotrophic spherical bacteria (Cho et al. 2004).

Although certain general patterns that are typical of freshwater lakes and rivers (Zwart et al. 2002), such as the dominance of the phyla Proteobacteria and Bacteroidetes, can also be observed in TDNP brackish 
waters, this system has a particular microbiota. We found 265 new phylogroups with similarity values below $97 \%$ and without close references in the public sequence repository. They belonged mainly to Proteobacteria, in particular, and more specifically to the families Burkholderiaceae, Rhodobacteraceae and Desulfobacteraceae. Thus, TDNP constitutes a reservoir of bacterial biodiversity characterised by a high number of new or previously not well described bacterial taxa.

\section{Bacteria related to the main biogeochemical cycles}

Bacterial heterotrophy in aquatic ecosystems is important in the overall carbon cycle (Van Mooy et al. 2001). There is a great amount of emergent aquatic vegetation (mainly reed and saw grass) surrounding the water in TDNP (Alvarez-Cobelas et al. 2008), and there are also charophyte meadows, which account for a large quantity of organic matter (OM). The degradation of autochthonous $\mathrm{OM}$ in this ecosystem requires the participation of several microbial partners (Docherty et al. 2006). Specialised bacteria will initially degrade complex polymers (e.g. cellulose, long fatty acids). Later, fermenting microorganisms will degrade simpler organics into small molecules (i.e. acetate) that can be utilised by acetogenic methanogens (Briée et al. 2007). Several TDNP lineages could perform such decomposition functions. Hydrogen, a major end-product of fermentation, is likely to be released into the environment, as there are some phylotypes related to hydrogen oxidising bacteria (e.g. Hydrogenophaga relatives). The main sink for hydrogen is probably constituted by methanogenic Archaea. At present, we do not have data about Archaea in TDNP, but the same kind of samples will be processed to assess archaeal diversity in the near future.

The sulphur cycle is also likely important in TDNP due to the high sulphate concentrations in water and sediments. Many bacterial sequences of families related to this cycle were found. For example, there was a large abundance of clone sequences related to phototrophic sulphur bacteria (like Ectothiorodospiraceae and Chromatiaceae) or to the Alphaproteobacteria Rhodospirillaceae. In a parallel study, phototrophic bacteria containing bacteriochlorophyll $a$ and living in aerobic conditions were detected forming a conspicuous microbial mat during summer, in the vicinity of our sampling point (M. A. Rodrigo et al. unpubl. data). Aerobic anoxygenic phototrophs (AAP; belonging to Alpha- and Gammaproteobacteria) have been described for marine habitats and more recently for freshwater systems (Page et al. 2004, Gich \& Overmann 2006). Masin et al. (2008) reported on the impor- tant and widespread distribution of such phototrophs (containing bacteriochlorophyll a) in freshwater environments. They are obligate aerobes because they require oxygen for respiration and growth. We found sequences related to Erythrobacter, which has been described as containing bacteriochlorophyll $a$, although this is a marine genus (Yurkov \& Beatty 1998). TDNP could be an additional environment where AAP is found. Sequences belonging to 3 families of sulphate-reducing bacteria (Desulfobacteraceae, Desulfobulbaceae and Desulfomicrobiaceae) were also present in W and US samples only. We expected to find this group in the other habitats under study, but no sulphate-reducing bacterial sequences were found in LS and B samples, the reasons for which remain unknown. Most sulphate-reducing sequences of the family Desulfobacteraceae retrieved from TDNP are not affiliated with sequences of described and cultured species found in the database.

The microbial nitrogen cycle is very complex and the major players involved are not fully known (Jetten 2008). Regarding bacteria in TDNP that could be involved in the nitrogen cycle, sequences close to the family Rhizobiaceae were retrieved only in LS and B samples. Since the biofilm was within emergent palustrine vegetation, this fact could explain the presence of members (maybe symbiotic nitrogen-fixing species) of this family. Other clone sequences could be affiliated to bacteria related to the nitrogen cycle, such as those belonging to the phyla Nitrospira or Planctomycetes. However, these sequences do not confidently match any known genera.

\section{CONCLUSIONS}

It is becoming increasingly clear that wetland microbial communities influence important processes at the ecosystem level (including nutrient cycling and decomposition; Farnell-Jackson \& Ward 2003) and there is a clear relationship between structure and functioning in ecosystems (Logue et al. 2008). This highlights the importance of knowing the microbial community structure. Our study has contributed to the description of the bacterial community structure in some of the main compartments of a wetland (water, water-sediment interface, sediment and biofilm related to aquatic vegetation) in the summer season. These preliminary results point out that each kind of environment harbours an idiosyncratic microbiota. This may suggest that each environment fulfils special conditions for the growth of certain kinds of bacteria. In addition, the study reveals that TDNP wetland is rich in new types of bacteria. Further studies are required to discover the relationship between structure and functioning. 
Acknowledgements. We thank the Instituto de Recursos Naturales (CSIC, Madrid) field team and M. Álvarez-Cobelas for their collaboration. M. J. Pujalte offered valuable suggestions. M.M.B.R. held a pre-doctoral grant funded by the University of Valencia. G.D. has a research contract from CIBERESP. Sequencing was carried out using facilities of the SCSIE (University of Valencia). This work was supported by project BFU2006/06003 to A.L. and by project 81/206 from the Spanish Environment Ministry (Autonomous Organism of National Parks).

\section{LITERATURE CITED}

Ahn C, Gillevet PM, Sikaroodi M (2007) Molecular characterization of microbial communities in treatment microcosm wetlands as influenced by macrophytes and phosphorus loading. Ecol Indic 7:852-863

Altschul SF, Gish W, Miller W, Myers EW, Lipman DJ (1990) Basic local alignment search tool. J Mol Biol 215:403-410

- Alvarez-Cobelas M, Cirujano S, Sanchez-Carrillo S (2001) Hydrological and botanical man-made changes in the Spanish wetland of Las Tablas de Daimiel. Biol Conserv 97:89-98

Alvarez-Cobelas M, Sanchez-Carrillo S, Cirujano S, Angeler DG (2008) Long-term changes in spatial patterns of emergent vegetation in a Mediterranean floodplain: natural versus anthropogenic constraints. Plant Ecol 194:257-271

APHA-AWWA-WEF (2005) Standard methods for the examination of water and wastewaters. American Public Health Association, American Water Works Association and Water Environment Federation, Washington, DC

Baik KS, Park SC, Kim EM, Bae KS and others (2008) Diversity of bacterial community in freshwater of Woopo wetland. J Microbiol 46:647-655

Baker GC, Smith JJ, Cowan DA (2003) Review and re-analysis of domain-specific $16 \mathrm{~S}$ primers. J Microbiol Methods 55:541-555

Basu BK, Kalff J, Pinel-Alloul B (2000) The influence of macrophyte beds on plankton communities and their export from fluvial lakes in the St Lawrence River. Freshw Biol 45:373-382

Bottger EC (1989) Rapid determination of bacterial ribosomal RNA sequences by direct sequencing of enzymatically amplified DNA. FEMS Microbiol Lett 65:171-176

Briée C, Moreira D, López-García P (2007) Archaeal and bacterial community composition of sediment and plankton from a suboxic freshwater pond. Res Microbiol 158: 213-227

> Cho JC, Vergin KL, Morris RM, Giovannoni SJ (2004) Lentisphaera araneosa gen. nov., sp. nov, a transparent exopolymer producing marine bacterium, and the description of a novel bacterial phylum, Lentisphaerae. Environ Microbiol 6:611-621

- Cirujano S, Casado C, Bernues M, Camargo JA (1996) Ecological study of Las Tablas de Daimiel National Park (Ciudad Real, central Spain): differences in water physicochemistry and vegetation between 1974 and 1989. Biol Conserv 75:211-215

Cobelas A, Sánchez-Soler MJ, Carrasco M, García-Consuegra B, Escuderos J, Alvarez-Cobelas M (1996) Las Tablas de Daimiel, ecología acuática y sociedad. Organismo autónomo Parques Nacionales, Madrid

> Cole JR, Wang Q, Cardenas E, Fish J and others (2009) The Ribosomal Database Project: improved alignments and new tools for rRNA analysis. Nucleic Acids Res 37: D141-D145
Docherty KM, Young KC, Maurice PA, Bridgham SD (2006) Dissolved organic matter concentration and quality influences upon structure and function of freshwater microbial communities. Microb Ecol 52:378-388

> Farnell-Jackson EA, Ward AK (2003) Seasonal patterns of viruses, bacteria and dissolved organic carbon in a riverine wetland. Freshw Biol 48:841-851

Garrity GM, Bell JA, Lilburn T (2005) The revised road map to the manual. In: Bergey's manual of systematic bacteriology, Vol II. Springer, New York

> Ghosh A, Maity B, Chakrabarti K, Chattopadhyay D (2007) Bacterial diversity of east Calcutta wet land area: possible identification of potential bacterial population for different biotechnological uses. Microb Ecol 54:452-459

Gich F, Overmann J (2006) Sandarakinorhabdus limnophila gen. nov., sp nov., a novel bacteriochlorophyll a-containing, obligately aerobic bacterium isolated from freshwater lakes. Int J Syst Evol Microbiol 56:847-854

Gich F, Garcia-Gil J, Overmann J (2001) Previously unknown and phylogenetically diverse members of the green nonsulfur bacteria are indigenous to freshwater lakes. Arch Microbiol 177:1-10

> Hahn MW (2006) The microbial diversity of inland waters. Curr Opin Biotechnol 17:256-261

Hall TA (1998) BioEdit: a user-friendly biological sequence alignment editor and analysis program for Windows 95/98/NT. Nucleic Acids Symp Ser 41:95-98

Hammer Ø, Harper DAT, Ryan PD (2001) PAST: paleontological statistics software package for education and data analysis. Palaeontol Electronica 4(1):9

Heras G, Prieto E, Guerrero T, Onate JM and others (1971) Recursos y aprovechamientos hidráulicos. Consejo económico-sindical interprovincial de La Mancha, Ciudad Real

Holmfeldt K, Dziallas C, Titelman J, Pohlmann K, Grossart HP, Riemann L (2009) Diversity and abundance of freshwater Actinobacteria along environmental gradients in the brackish northern Baltic Sea. Environ Microbiol 11: 2042-2054

Jetten MSM (2008) The microbial nitrogen cycle. Environ Microbiol 10:2903-2909

Kovacs G, Burghardt J, Pradella S, Schumann P, Stackebrandt E, Marialigeti K (1999) Kocuria palustris sp. nov. and Kocuria rhizophila sp. nov., isolated from the rhizoplane of the narrow-leaved cattail (Typha angustifolia). Int J Syst Bacteriol 49:167-173

Kumar S, Nei M, Dudley J, Tamura K (2008) MEGA: a biologist-centric software for evolutionary analysis of DNA and protein sequences. Brief Bioinform 9:299-306

Lane DDJ (1991) 16S/23S rRNA sequencing. John Wiley \& Sons, London

> Lehours AC, Evans P, Bardot C, Joblin K, Gerard F (2007) Phylogenetic diversity of archaea and bacteria in the anoxic zone of a meromictic lake (Lake Pavin, France). Appl Environ Microbiol 73:2016-2019

Li W, Godzik A (2006) Cd-hit: a fast program for clustering and comparing large sets of protein or nucleotide sequences. Bioinformatics 22:1658-1659

> Linley EAS, Newell RC, Lucas MI (1983) Quantitative relationships between phytoplankton, bacteria and heterotrophic microflagellates in shelf waters. Mar Ecol Prog Ser 12:77-89

> Liu FH, Lin GH, Gao G, Qin BQ and others (2009) Bacterial and archaeal assemblages in sediments of a large shallow freshwater lake, Lake Taihu, as revealed by denaturing gradient gel electrophoresis. J Appl Microbiol 106: 1022-1032

Logue JB, Burgmann H, Robinson CT (2008) Progress in the 
ecological genetics and biodiversity of freshwater bacteria. BioScience 58:103-113

Masin M, Nedoma J, Pechar L, Koblizek M (2008) Distribution of aerobic anoxygenic phototrophs in temperate freshwater systems. Environ Microbiol 10:1988-1996

Mitsch WE, Gosselink JG (2000) Wetlands. Wiley \& Sons, New York

Niederberger TD, McDonald IR, Hacker AL, Soo RM, Barrett JE, Wall DH, Cary SC (2008) Microbial community composition in soils of Northern Victoria Land, Antarctica. Environ Microbiol 10:1713-1724

OECD (Organisation for Economic Co-operation and Development) (1982) Eutrophication of waters. Monitoring, assessment and control - Technical Report. OECD, Paris

Ortega-Mayagoitia E, Armengol X, Rojo C (2000) Structure and dynamics of zooplankton in a semi-arid wetland, the National Park Las Tablas de Daimiel (Spain). Wetlands 20:629-638

Ortega-Mayagoitia E, Rodrigo MA, Rojo C, Alvarez-Cobelas M (2002) Picoplankton dynamics in a hypertrophic semiarid wetland. Wetlands 22:575-587

Page KA, Connon SA, Giovannoni SJ (2004) Representative freshwater bacterioplankton isolated from Crater Lake, Oregon. Appl Environ Microbiol 70:6542-6550

Porter KG, Feig YS (1980) The use of DAPI for identifying and counting aquatic microflora. Limnol Oceanogr 25:943-948

Rodrigo MA, Rojo C, Alvarez-Cobelas M (2003) Autotrophic and heterotrophic picoplankton in wetlands: differences with lake patterns. Int Rev Hydrobiol 88:464-481

Rojo C, Ortega-Mayagoitia E, Rodrigo MA, Alvarez-Cobelas M (2000) Phytoplankton structure and dynamics in a semiarid wetland, the National Park 'Las Tablas de Daimiel' (Spain). Arch Hydrobiol 148:397-419

Sanchez-Carrillo S, Alvarez-Cobelas M (2001) Nutrient dynamics and eutrophication patterns in a semi-arid wetland: the effects of fluctuating hydrology. Water Air Soil Pollut 131:97-118

Editorial responsibility: Jed Fuhrman,

Los Angeles, California, USA
Shannon CE, Weaver W (1963) The mathematical theory of communication. University of Illinois Press, Urbana, IL

Shrestha PM, Kube M, Reinhardt R, Liesack W (2009) Transcriptional activity of paddy soil bacterial communities. Environ Microbiol 11:960-970

Stevens H, Brinkhoff T, Simon M (2005) Composition of free-living, aggregate-associated and sediment surfaceassociated bacterial communities in the German Wadden Sea. Aquat Microb Ecol 38:15-30

Steward GF, Jenkins BD, Ward BB, Zehr JP (2004) Development and testing of a DNA macroarray to assess nitrogenase (nifH) gene diversity. Appl Environ Microbiol 70: 1455-1465

Van Mooy B, MacGregor B, Hollander D, Nealson K, Stahl D (2001) Evidence for tight coupling between active bacteria and particulate organic carbon during seasonal stratification of Lake Michigan. Limnol Oceanogr 46:1202-1208

> Weisburg WG, Barns SM, Pelletier DA, Lane DJ (1991) 16S ribosomal DNA amplification for phylogenetic study. J Bacteriol 173:697-703

Yakimov MM, Gentile G, Bruni V, Cappello S, D'Auria G, Golyshin PN, Giuliano L (2004) Crude oil-induced structural shift of coastal bacterial communities of rod bay (Terra Nova Bay, Ross Sea, Antarctica) and characterization of cultured cold-adapted hydrocarbonoclastic bacteria. FEMS Microbiol Ecol 49:419-432

> Yurkov VV, Beatty JT (1998) Aerobic anoxygenic phototrophic bacteria. Microbiol Mol Biol Rev 62:695-724

- Zaballos M, Lopez-Lopez A, Ovreas L, Bartual SG and others (2006) Comparison of prokaryotic diversity at offshore oceanic locations reveals a different microbiota in the Mediterranean Sea. FEMS Microbiol Ecol 56: 389-405

Zwart G, Crump BC, Kamst-van Agterveld MP, Hagen F, Han SK (2002) Typical freshwater bacteria: an analysis of available 16S rRNA gene sequences from plankton of lakes and rivers. Aquat Microb Ecol 28:141-155

Submitted: April 8, 2009; Accepted: October 1, 2009

Proofs received from author(s): March 2, 2010 